\title{
A Study on Customer Relationship Quality and Customer Citizenship Behavior -Evidence from Online Shopping Behavior of College Students
}

\author{
Xiangyu Meng ${ }^{1, \text { a, }}$, Guicheng Shi ${ }^{2, \mathrm{~b}}$, Xianyong Meng ${ }^{1, \mathrm{c}}$, Zhengbo Wang ${ }^{3, \mathrm{~d}}$ \\ ${ }^{1}$ Zhuhai College of Jilin University, Zhuhai, China \\ ${ }^{2}$ Macau University of Science and Technology, Macau, China \\ ${ }^{3}$ Department of Economics and Related Studies, University of York, York, UK \\ amengmarc@163.com, 'gcshi@must.edu.mo, 'meng_xianyong@hotmail.com, W'Wang_zhengbo@hotmail.com
}

\begin{abstract}
The authors propose a conceptual model that links online vendors' attributes, online relationship quality, and customer citizenship behavior. They estimate this model on data from 288 consumers across 15 sites, using structural equation analysis. The results show that order fulfillment is the most influential determinants of online relationship quality for online vendors.
\end{abstract}

Keywords-online vendors' attributes; online relationship quality; customer citizenship behavior.

\section{INTRODUCTION}

In the contemporary retailing environment, information technology-based retail format-online vendors have become popular.

Like organizational employees, customers may engage in a variety of citizenship behavior directed toward a specific organization. And service organizations should really view customers, at least in some senses, as organizational members or employees (Kelley, Donnelly, \& Skinner, 1990). Therefore, it is critical for online sellers to satisfy consumers with the goals of making repeated profits and encouraging them to perform customer citizenship behavior.

The purpose of this study is to propose and test an integrative theoretical model that identify the relative importance of each online store attribute on market response outcomes (i.e., trust, satisfaction, and loyalty)

\section{A. Website Navigation of Online Vendor}

Website navigation refers to the appearance, layout, and possible sequence of clicks, images, and paths on a Web site (Yakov, Shankar, Sultan \& Glen, 2005).

The user's first impression upon visiting a homepage creates bias about a company or an organization that affects the consumers' mental image and affects all aspects of the business.

In fact, the site's success can be estimated by the level of web navigation, usability, and the variety of media found on an e-commerce site (Palmer 2002). This means visual elements do stimulate consumers' online shopping.

\section{B. Order Fulfillment}

Order fulfillment refers to the delivery of a product or service relative to orders placed by consumers, and it is an essential aspect of Web sites with transactional ability (Yakov et al., 2005). In online retailing, the fulfillment process can be understood to consist of three stages: order acceptance, order selection, and order delivery (Stock \& Boyer. 2009).

Increasingly, it is believed that effective order fulfillment of promised delivery serves as a means of satisfaction and customer delight (Rao Goldsby, Griffis \& Iyengar, 2011).

Order fulfillment provides online shoppers with the value of time and space and allows shoppers to accomplish their purchasing tasks in a deliberate and efficient manner, therefore, it increases the utilitarian value of online shopping. Moreover, order fulfillment also provides online customers with the benefits of perceived freedom and fantasy fulfillment, which may indicate a hedonically valuable shopping experience.

\section{Security}

Security on a Web site refers to the safety of the computer and credit card or financial information (Yakov et al. 2005).Because online consumers interact with the web interface rather than sales personnel, security is the main concern regarding the factor of assurance. Security concerns the risk of third parties obtaining critical information about the consumer (e.g., access to credit card or bank account details), whereas privacy concerns about the potential misuse of personal information by marketers.

\section{Online Relationship Quality}

Relationship quality is focused more on long-term customer relationships rather than on short-term transactions. Previous researchers have shown that a high quality relationship can earn life-long customer commitment and is valuable or a business.

Crosby et al. (1990) suggested that relationship quality comprises two parts, trust and satisfaction, which are each considered an "emotional state that occurs in response to an evaluation of these interaction experiences" (Westbrook, 1981) Relationship quality can be defined as a construct composed of several distinct but related facets such as trust, commitment, identification, intimacy, and reciprocity, which reflect overall assessment of strength and depth of relationships between organizations and consumers (De 
Wulf, Odekerken-Schröder, \& Iacobucci, 2001; Fournier, 1998; Palmatier, Dant, Grewal, \& Evans, 2006).

\section{E. Customer Citizenship Behavior}

In recent years, there has been an increasing focus on customer citizenship behavior in the managerial and marketing literature (Aherne, Bhattacharya, \& Gruen, 2005; Bettencourt, 1997; Groth, 2005; Lengnick-Hall, Claycomb, \& Inks, 2000).

Customer citizenship behavior is defined as "voluntary and discretionary behavior of individual customers that is not directly or explicitly expected or rewarded but that in the aggregate, leads to higher quality service and promotes the effective functioning of service organizations" (Groth, 2005). Consumers routinely act as employees of firms by voluntarily performing tasks that firm employees would otherwise undertake. Such voluntary behaviors are termed customer citizenship behaviors by Groth (2005) and are 'helpful, discretionary behaviors of customers that support the ability of the firm to deliver service quality' (Bettencourt, 1997).

Like organizational employees, customers may engage in a variety of citizenship behavior directed toward a specific organization. Bowen (1986) argues that "a central difference between service and manufacturing firms is that customers are often physically present when the service is provided, quite unlike manufacturing firms where customers are only rarely present during production." Therefore, both customers and employees constitute the human resource of the service organization. Customers often perform the work that employees might otherwise perform, so that customers may even replace employees in service-based organizations (Halbe-sleben \& Buckley, 2004). Previous research has proposed that service organizations should really view customers, at least in some senses, as organizational members or employees (Kelley, Donnelly, \& Skinner, 1990).

\section{RESEARCH MODEL AND HyPOTHESES}

- Hypothesis 1: Website navigation has a positive and direct influence on online relationship quality.

- Hypothesis 2: Fulfillment has a positive and direct influence on online relationship quality.

- Hypothesis 3: Security has a positive and direct influence on online relationship quality.

- Hypothesis 4: A higher level of online relationship quality leads to a higher level of customer citizenship behavior.

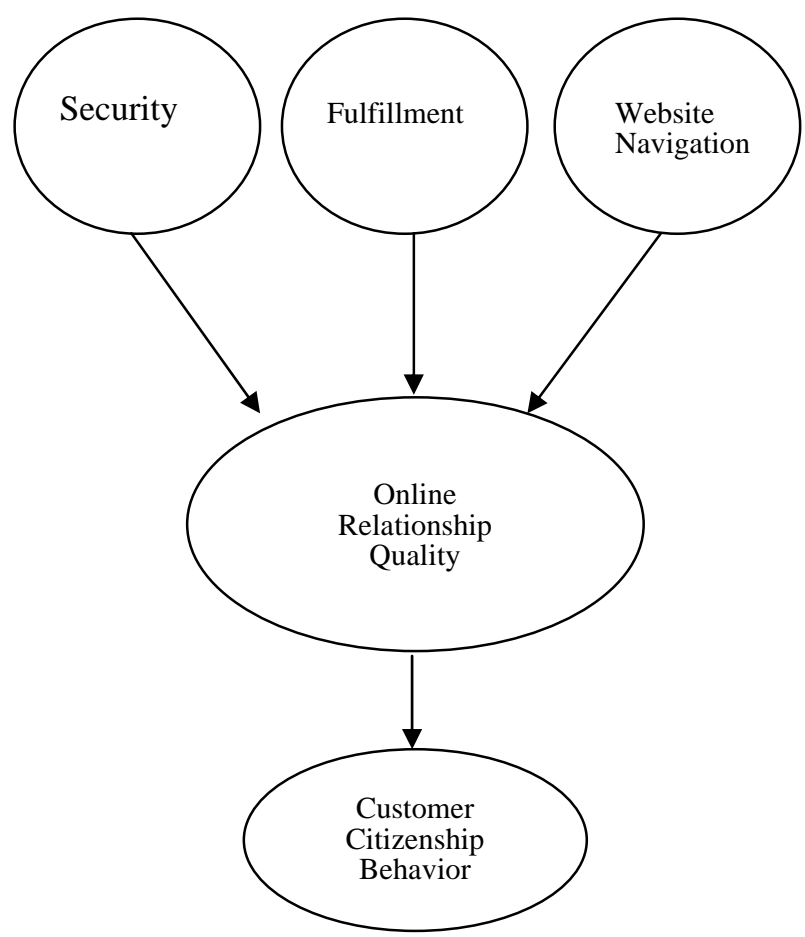

Figure 1. Research model and hypotheses

\section{METHOD}

The first challenge in sales force sampling concerns properly defines the population of study. Lim and Dubinsky (2004) asserted that the student sample is appropriate for querying online consumers since college students spend more than 20 hours per week on the Internet, and $81 \%$ of them have made purchases online.

Most surveys were collected in online questionnaires. Many researchers have employed online register lists or databases to get the sample for their online consumer surveys (e.g.,Anderson \& Srinivasan, 2003; Ba \& Pavlou, 2002; Evanschitzky et al., 2004; Koufaris et al., 2002).

Since online consumers have different preferred online retailers due to reasons such as familiarity, product preference, and the availability of additional service, it is not effective to ask all the customers to evaluate the same online retailer. Therefore, this research takes a similar approach to Kim and Stoel's (2004) study, asking around 200 respondents to give evaluation of online relationship quality, trust, satisfaction, commitment and customer citizenship behavior based on one of their most satisfactory experience with their most favorite online retailer; around 200 respondents to give evaluation of online relationship quality based one of their most dissatisfactory experiences; around 200 respondents to give evaluation of online relationship quality based one of their very normal (neutral) online shopping experiences. 


\section{IV.MODEL AND HyPOTHESES TESTING}

The main part of data analysis focused on hypothesis testing. A structural equation modeling (SEM) procedure was employed to test these hypotheses. Essentially, SEM may be viewed as a combination of exploratory factor analysis and multiple regression analyses (Ullman, 2001). In contrast to exploratory factor analysis, SEM demands that the (presumably causal) structure of intervariable relations, grounded in theory and/or empirical findings, be specified a priori. perception of online relationship quality, online vendors have to give priority to the order fulfillment improvement.

Another important finding is that higher level of online relationship quality lead to increased customer citizenship behavior intentions. To explain these results, we argue that stronger relationship between online vendors and their customers broadens the online vendor's social network, which in turn, plays a very important role in the occurrences of customer citizenship behavior. Thus, online relationship quality may be an important determinant of customer citizenship behavior. In online business context where building customer citizenship behavior is critical, the online relationship quality can affect customer relationships and is

TABLE I. STRUCTURAL MODEL TESTING RESULTS

\begin{tabular}{|c|c|c|c|c|}
\hline Path & Hypothesis & Estimates & T-value & Supported \\
\hline $\begin{array}{l}\text { Website Navigation } \\
\rightarrow \text { Online Relationship Quality }\end{array}$ & H1 & -0.261 & -1.804 & $\mathrm{~N}$ \\
\hline $\begin{array}{l}\text { Fulfillment } \\
\rightarrow \text { Online Relationship Quality }\end{array}$ & $\mathrm{H} 2$ & 0.399 & $2.087^{*}$ & $\mathrm{Y}$ \\
\hline $\begin{array}{l}\text { Security } \\
\rightarrow \text { Online Relationship Quality }\end{array}$ & H3 & -0.018 & -0.356 & $\mathrm{~N}$ \\
\hline $\begin{array}{l}\text { Online } \quad \text { Relationship } \quad \text { Quality } \rightarrow \\
\text { Customer Citizenship Behavior }\end{array}$ & $\mathrm{H} 4$ & 0.739 & $10.781^{* * *}$ & $\mathrm{Y}$ \\
\hline
\end{tabular}

The analyses were conducted using AMOS 21, and followed guidelines suggested by Byrne (2001) and Ullman (2001). AMOS was chosen over other model fitting programs such as LISREL and EQS, for its unique strength in preventing errors in model specification (Kline, 2005), and its extensive bootstrapping capabilities, which is an effective tool for dealing with non-normal data (RundleThiele, 2005).

Based on the t-values of the standardized parameter estimates in above tables, a summary of the structural model testing results is shown in Table 1.

According to Table 1 , the results fully supported Hypothesis 2 and Hypothesis 4. While Hypothesis 1 and Hypothesis 3 are not supported.

\section{CONCLUSIONS}

This study empirically supported that effective order fulfillment of promised delivery serves as a means of satisfaction and customer delight (Boyer and Hult 2005). Urban et al. (2000) suggested that the important factor leading to trust is fulfillment. Unsurprisingly, when consumers are concerned about the products they buy from an online vendor and lack the required trust on the vendor, they may rely on the order fulfillment track record of online vendors' web site. Thus, order fulfillment may be an important determinant of online customer relationship quality. As a consequence, in order to strengthen the valuable for online vendors and web sites.

\section{REFERENCES}

[1] Kelley S W, Donnelly J H, Skinner S J.(1990).Customer participation in service production and delivery. Journal of retailing., 37(1), 124161.

[2] Yakov Bart, Venkatesh Shankar, Fareena Sultan, \& Glen L. Urban.(2005). Are the Drivers and Role of Online Trust the Same for All Web Sites and Consumers? A Large-Scale Exploratory Empirical Study. Journal of Marketing, Vol. 69 (October 2005), 133-152.

[3] Palmer, J. W. (2002). Web site usability, design, and performance metrics. Information systems research, 13(2), 151-167.

[4] Stock, J. R., \& Boyer, S. L. (2009). Developing a consensus definition of supply chain management: a qualitative study. International Journal of Physical Distribution \& Logistics Management, 39(8), 690-711.

[5] Boyer, K.K., \& Hult, T.G. (2005) "Customer Behavior in Online Ordering: A Decision Scoring Model.” Decision Sciences 36(4):569_ 98.

[6] Rao, S., Goldsby, T. J., Griffis, S. E., \& Iyengar, D. (2011).(2011a).“Electronic Logistics Service Quality (e-LSQ): Its Impact on the Customer's Purchase Satisfaction and Retention.” Journal of Business Logistics, 30(2), 167-179.

[7] Westbrook, C. K., \& Dryer, F. L. (1981). Simplified reaction mechanisms for the oxidation of hydrocarbon fuels in flames, 27(12), 31-43.

[8] Wulf, K. D., Odekerken-Schröder, G.., \& Iacobucci, D. (2001). Investments in consumer relationships: a cross-country and crossindustry exploration.Journal of Marketing, 65(4), 33-50.

[9] Fournier, S. (1998).Consumer and their brands: Developing relationship theory in consumer research. Journal of Consumer Research, 24(4), 343-374. 
[10] Palmatier, R. W., Dant, R. P., Grewal, D., \& Evans, K. R. (2006).Factors Influencing the Effectiveness of Relationship Marketing: A Meta-Analysis. Journal of Marketing, 70 (10), 136-53.

[11] Ahearne, Bhattacharya, \& Gruen, 2005;

[12] Ahearne, M., Bhattacharya, C. B., \& Gruen, T. (2005). Gruen T. Antecedents and consequences of customer-company identification: expanding the role of relationship marketing. Journal of applied psychology, 90(3): 574.

[13] Bettencourt L. A. (1997).Customer voluntary performance: customers as partners in service delivery. Journal of retailing, 73(3), 383-406.

[14] Groth, M (2005) Customers as good soldiers: Examining citizenship behaviors in internet service deliveries. Journal of Management, 31(2), 7-27.

[15] Lengnick-Hall, C. A., Claycomb, V. C., \& Inks, L. W. (2000).From recipient to contributor: examining customer roles and experienced outcomes. European Journal of Marketing, 34(3/4), 359-383.

[16] Halbesleben J. R. B., \& Buckley M R. (2004).Burnout in organizational life. Journal of management, 30(6), 859-879.

[17] Anderson, R. E., \& Srinivasan, S. S. (2003). E-satisfaction and eloyalty: A contingency framework. Psychology and Marketing, 20(2), 123-138.
[18] Ba, S., \& Pavlou, P. A. (2002). Evidence of the effect of trust building technology in electronic markets: Price premiums and buyer behavior. MIS quarterly, 7(10), 243-268.

[19] Evanschitzky, H., Iyer, G. R., Hesse, J., \& Ahlert, D. (2004). Esatisfaction: a re-examination. Journal of Retailing, 80(3), 239-247.

[20] Koufaris, M. (2002). Applying the technology acceptance model and flow theory to online consumer behavior. Information Systems Research, 13(2), 205-223.

[21] Ullman, J. B. (2001). Structural Equation Modeling. In B. G. Tabachnik, \& L. S. Fidell (Eds.), Using Multivariate Statistics (4th ed.): Allyn and Bacon.

[22] Kline, R.B. (2005), Principles and practices of structural equation modeling. New York: Guilford.

[23] Rundle-Thiele, 2005Kolesar, M. B., \& Galbraith, R. W. (2000). A services-marketing perspective on e-retailing: implications for eretailers and directions for further research. Internet Research, 10(5), 424-438.

[24] Hair, J. F., Anderson, R. E., Tatham, R. L., \& Black, W. C. (1995). Multivariate data analysis with readings Prentice-Hall. Englewood Cliffs, NJ, 32(6), 189-232. 